\title{
Nearshore ichthyoplankton associated with seagrass beds in the lower Chesapeake Bay
}

\author{
John E. Olney ${ }^{1}$, George W. Boehlert ${ }^{2}$ \\ ${ }^{1}$ Virginia Institute of Marine Science and School of Marine Science, College of William and Mary, Gloucester Point, \\ Virginia 23062, USA \\ ${ }^{2}$ Southwest Fisheries Center Honolulu Laboratory, National Marine Fisheries Service, NOAA, 2570 Dole Street, \\ Honolulu, Hawaii 96822-2396, USA
}

\begin{abstract}
Estuaries serve as important nursery habitats for larvae and juveniles of many species of fishes and invertebrates. Within the estuary, however, partitioning may occur among main channel, mud flat, tidal creek, and vegetated habitats. In this study we describe the egg, larval, and juvenile fish assemblages in shallow areas of submerged aquatic vegetation (SAV) of the lower Chesapeake Bay and compare them with those over the adjacent, shallow sand habitat. Densities at night over all habitats were about 1 order of magnitude higher than daytime densities, and were highest in summer. The SAV habitats were not important spawning sites for species with pelagic eggs, but were important for species brooding eggs or with demersal eggs. Overall, collections were dominated by the bay anchovy Anchoa mitchilli, but contained many species not commonly found in the midchannel ichthyoplankton described in earlier studies; these include the croaker Micropogonias undulatus, rough silverside Membras martinica and northern pipefish Syngnathus fuscus. Conversely, the weakfish Cynoscion regalis was rare in our collections as compared to main channel sampling areas. Our results suggest that SAV areas do not play an important nursery role for pelagic eggs and early larvae, which may suffer increased predation by planktivores in these areas. Later stages, however, may benefit from reduced predation pressure from piscivores and thus benefit from association with SAV
\end{abstract}

\section{INTRODUCTION}

The shallow, vegetated areas of estuaries serve an important role as nursery habitats for early life history stages of fishes and shrimps (Reid 1954, Carr \& Adams 1973, Adams 1976, Orth \& Heck 1980, Weinstein \& Brooks 1983). The most frequently cited benefits of estuarine residence include enhanced prey availability (Houde \& Lovdal 1984), and especially reduced predation (Rosenberg 1982, Bell et al. 1987). Predation may be reduced through increased turbidity in estuaries (Blaber \& Blaber 1980, Boehlert \& Morgan 1985) or through use of more structurally complex shallowwater areas not readily accessible to predators. Habitat complexity is increased by the presence of seagrass, and this apparently plays an added role in reduction of predation (Lascara 1981, Savino \& Stein 1982, Minello \& Zimmerman 1983, Heck \& Thoman 1984). Although the juvenile and adult fishes in these seagrass beds have been surveyed (Orth \& Heck 1980), relatively little is known about the importance of this habitat for fish eggs and larvae.
Within the lower Chesapeake Bay, late larval and juvenile fishes occupying seagrass habitats either immigrate from offshore spawning grounds or result from local spawning activity. In the former case, earliest development occurs in offshore waters and movement to the nearshore waters near inlets may be mediated by Ekman transport (Miller et al. 1984). Subsequent movement through inlets and habitat selection within estuaries is thought to depend upon behavioral mechanisms (Boehlert \& Mundy 1988). Data on spawning activity of resident species are available from previous characterizations of Chesapeake Bay ichthyplankton (Pearson 1941, Dovel 1971, Olney 1983). These studies have concentrated on midchannel portions of the estuary and have neglected the generally inaccessible nearshore, shallow environments. As a result, the extent to which nearshore vegetated zones serve as spawning habitats for resident Chesapeake Bay fishes, particularly those with pelagic eggs, is unknown. Some resident species, especially those that brood eggs or have demersal eggs, are known to spawn in these nearshore habitats. For species with pelagic eggs, how- 


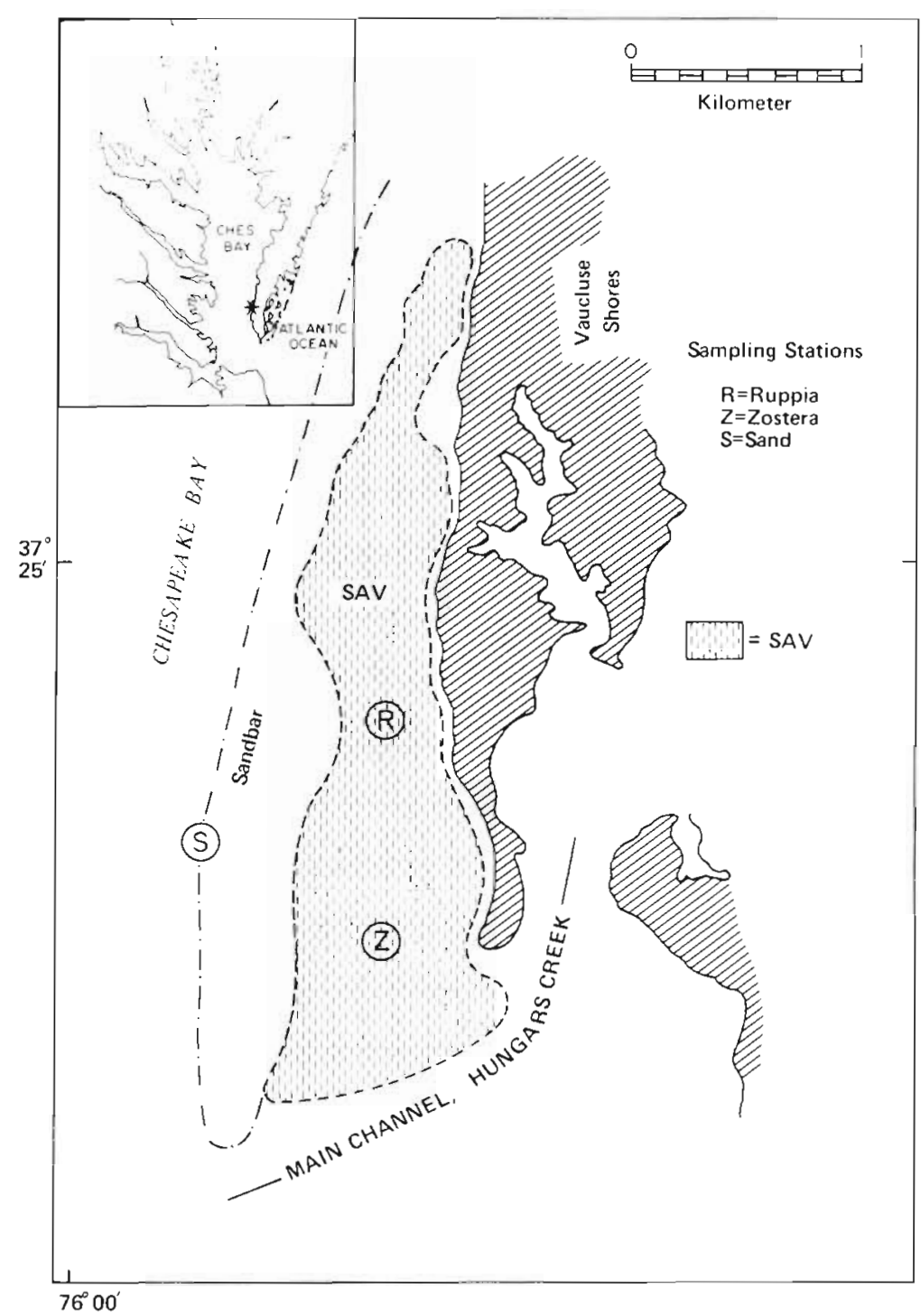

Fig. 1. Detail of sampling site at Vaucluse Shores, Virginia, USA. Inset locates study site $(\star)$ in Chesapeake Bay region. Pushnet samples were taken in Zostera (Z), Ruppia (R), and Sand (S) ever, it is likely that tidal flushing or predation by resident planktivores would remove such eggs from the area.

In the Chesapeake Bay, areas of seagrass beds have declined (Orth \& Moore 1983), possibly resulting in decreasing availability of nursery habitat. In the present study, we characterize nearshore ichthyoplankton associated with beds of Zostera marina and Ruppia maritima and examine spatial and temporal trends in recruitment of larval and early juvenile fishes to these shallow-water habitats. Finally, we evaluate the use of vegetated zones as spawning sites for resident Chesapeake Bay fishes.

\section{MATERIALS AND METHODS}

The sampling site was located on the eastern side of Chesapeake Bay, Virginia, USA (ca $37^{\circ} 25^{\prime} \mathrm{N}$, $75^{\circ} 59^{\prime} \mathrm{W}$ ) in an area known locally as Vaucluse Shores (Fig. 1). Three sampling stations, designated as Zostera, Ruppia, and Sand, were established within the nearshore system. Sampling depths typically ranged from 1.5 to $3 \mathrm{~m}$. To avoid disturbance to the seagrass and bottom in these shallow waters, we used a bowmounted pushnet (Fig. 2) similar to that described by Miller (1973) deployed from a $5.8 \mathrm{~m}$ outboard skiff. The pushnet was equipped with a $1 \mathrm{~m}, 505 \mu \mathrm{m}$ mesh and two $18.5 \mathrm{~cm}, 202 \mu \mathrm{m}$ mesh plankton nets fitted with calibrated General Oceanics " flowmeters. Nets were fished at night during slack high tide for 2 to $3 \mathrm{~min}$ depending on abundance of plankton. The sampling duration and boat speed allowed the ichthyoplankton net to cover 74 to $175 \mathrm{~m}^{2}$ of sea surface and filter from 68 to $117 \mathrm{~m}^{3}$ of water. Two replicate collections from

- Reference to trade names does not imply endorsement by the National Marine Fisheries Service, NOAA 
each station were made monthly and preserved in 5 to $10 \%$ laboratory grade formaldehyde in seawater buffered with sodium borate. In the laboratory, fish eggs and larvae were sorted from whole collections and identified to the lowest possible taxon. Larval lengths were measured with an ocular micrometer to the nearest $0.1 \mathrm{~mm}$. Densities were calculated in volumetric and areal terms.

\section{RESULTS}

\section{General composition}

The pushnet gear was effective for the collection of larval fish and zooplankton, as has been shown in other studies (Miller 1973, Hillman-Kitalong \& Birkeland 1987); for studies in shallow water it is particularly effective in minimizing turbulence from the vessel and propeller which can result in suspension of sediment and benthos. One drawback, however, is the effective sampling depth. Although our samples were all taken. in shallow water, station depths over sand were often. slightly deeper $(0.5$ to $1.5 \mathrm{~m})$ than in vegetated areas. Thus a smaller proportion of the water column may have been sampled over the sand habitat.

Pushnet sampling for ichthyoplankton resulted in 88 total collections (Zostera, $n=31$; Ruppia, $n=29$; Sand, $n=28$ ) on 14 dates from 26 March 1979 to 7 March 1980. Volumetric and areal estimates of sampling effort revealed moderate monthly variability and almost equal sampling effort among habitats. Sampling was conducted at least monthly through January 1980, but inclement weather in February 1980 delayed completion of the survey until 6 March 1980. Day-night com-

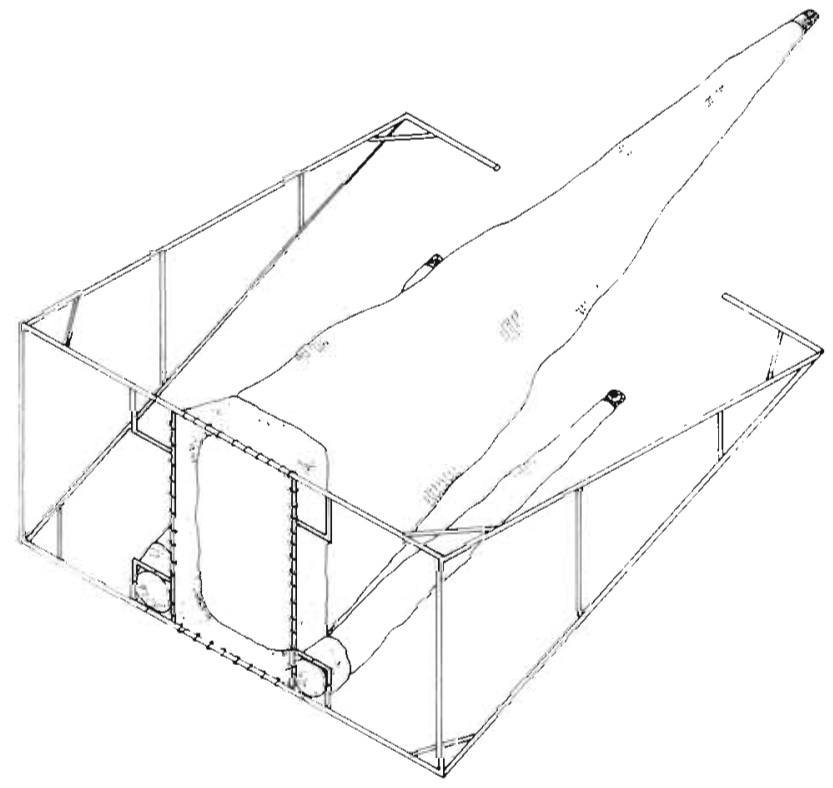

Fig. 2. Design of the pushnet sampling gear used to collect ichthyoplankton in the shallow-water areas; this design used a $1 \mathrm{~m}$ ichthyoplankton net and two $18.5 \mathrm{~cm}$ plankton nets. The 2 prongs were inserted into corresponding holes in the boat hull; the gear was carried in the boat and when deployed was swung forward and lowered over the bow of the boat. When the net was in use the top pipe was at the surface of the water

parison sampling was conducted on successive high tides during May and August 1979.

Temporal variability in hydrographic measurements was typical of shallow, nearshore environments, which are rapidly affected by short-term climatic changes (Fig. 3). Salinity, temperature, and dissolved oxygen samples were taken from the upper meter of the water column during sampling times; observed values (14.1 to $21.5 \%$; 1.5 to $28.0^{\circ} \mathrm{C} ; 6.6$ to $12.6 \mathrm{mg} \mathrm{l}^{-1}$, respec-
Fig. 3. Temperature and salinity measurements during the course of the study. These data are from the Zostera area during night sampling periods when ichthyoplankton samples were taken. Typically, there was little difference between the 3 areas at night

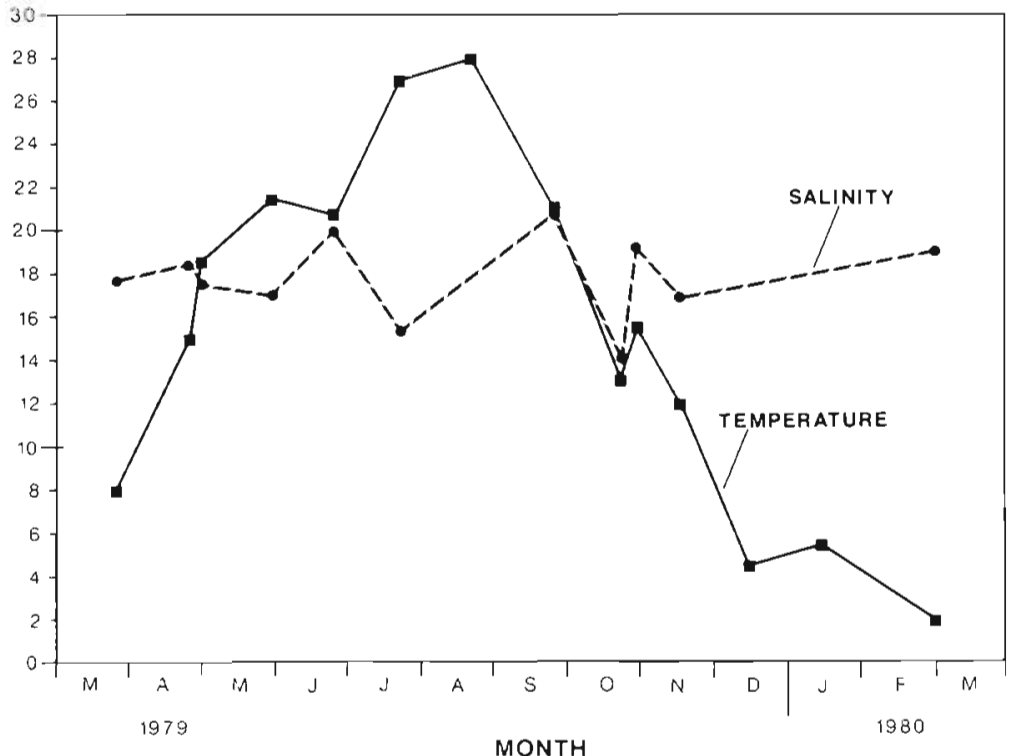


tively) were similar to those recorded by Orth \& Heck (1980). Occasionally, temperature and salinity varied widely between successive sampling periods as evidenced by measurements recorded on 27 September and 1 November 1979 (Fig. 3). Throughout the 12 mo period, hydrographic values did not vary markedly among habitats during any given sampling period. As a result, they were not considered important factors in comparisons of ichthyoplankton abundances among habitats.

Pushnet collections yielded 24354 fishes and 8631 eggs representing 34 species in 20 families (Table 1). Fish eggs were present during the 6 mo period March to August 1979 (Fig. 4A). Eggs of 6 species of fishes were identified in pushnet collections, and eggs of unidentified species of the families Gobidae and Sci- aenidae were also captured; numerical dominants were Anchoa mitchilli $(60.6 \%)$, the Sciaenidae $(35.7 \%)$ and Scopthalmus aquosus $(2.0 \%)$. Mean densities of pelagic eggs of $A$. mitchilli and the Sciaenidae were higher over sand bottom than over either vegetated zone (Fig. 4A). Although eggs of the hogchoker Trinectes maculatus are typically conspicuous components of lower Chesapeake Bay ichthyoplankton (Olney 1983), eggs were taken in very low abundance and only over sand habitats. Eggs of the halfbeak Hyporhamphus unifasciatus, the rough silverside Membras martinica, and gobies (Gobiidae) were taken in low densities, generally attached to floating Zostera blades or other plant material over vegetated habitats.

Of the 33 species occurring as larvae and juveniles, 8 species made up $96 \%$ of the total catch. A single

Table 1. Species, common name, life history stage and months of occurrence of fishes in pushnet collections, March 1979 to March 1980

\begin{tabular}{|c|c|c|c|c|c|c|c|c|c|c|c|c|c|c|}
\hline Species & Common name & Stage & M & A & $M$ & $\mathrm{~J}$ & $\mathrm{~J}$ & A & $\mathrm{S}$ & 01 & $N$ & $\mathrm{D}$ & $\mathrm{J}$ & M \\
\hline Anguilla rostrata & American eel & Elver & $\mathrm{x}$ & & & & & & & & & & & \\
\hline Alosa aestivalis & Blueback herring & Juvenile & $\mathrm{x}$ & $\mathrm{x}$ & & & & & & & & $X$ & & \\
\hline Alosa pseudoharengus & Alewife & Jurrenile & & & & & $x$ & & & & & & & \\
\hline Brevoortia tyrannus & Atlantic menhaden & Larva-juvenile & $x$ & $\mathrm{x}$ & $\mathrm{X}$ & $\mathrm{x}$ & & & & & $X$ & $\mathrm{X}$ & $\mathrm{x}$ & $\mathrm{X}$ \\
\hline Anchoa mitchilli & Bay anchovy & Egg-adult & $x$ & $\mathrm{x}$ & $\mathrm{X}$ & $\mathrm{x}$ & $\mathrm{X}$ & $\mathrm{x}$ & $\mathrm{x}$ & $x y$ & $X$ & $\mathrm{X} y$ & $\mathrm{x}$ & $\mathrm{X}$ \\
\hline Anchoa hepsetus & Striped anchovy & Larva-juvenile & & & & & $\mathrm{X}$ & $\mathrm{x}$ & & & & & & \\
\hline Gobiesox strumosus & Skilletfish & Larva & & & $\mathrm{X}$ & & & & & & & & & \\
\hline Hyporhamphus sp. & Halfbeak & Egg-juvenile & & & $\mathrm{X}$ & $\mathrm{x}$ & $\mathrm{X}$ & $\mathrm{x}$ & & & & & & \\
\hline Membras martinica & Rough silverside & Egg-adult & & $\mathrm{X}$ & $\mathrm{X}$ & $\mathrm{x}$ & $\mathrm{X}$ & $\mathrm{x}$ & $\mathrm{x}$ & $x>$ & $\mathrm{X}$ & & & \\
\hline Menidia menidia & Atlantic silverside & Adult & $x$ & $\mathrm{x}$ & & $\mathrm{x}$ & & & & & & $X$ & $\mathrm{x}$ & $\mathrm{x}$ \\
\hline Atherinidae & Silversides & Larvae & & $\mathrm{X}$ & $X$ & $\mathrm{X}$ & $\mathrm{X}$ & $x$ & $\mathrm{x}$ & & & & & \\
\hline Gasterosteus aculeatus & Threespine stickleback & Juvenile & & $\mathrm{X}$ & & & & & & & & & & \\
\hline Hippocampus erectus & Lined seahorse & Young & & & & & $\mathrm{X}$ & & & & & & & \\
\hline Syngnathus fuscus & Northern pipefish & Larva-adult & & & $x$ & $x$ & $\mathrm{X}$ & $\mathrm{x}$ & $\mathrm{X}$ & $\mathrm{x}$ x & $\mathrm{x}$ & & & \\
\hline Cynoscion regalis & Weakfish & Larva-juvenile & & & $\mathrm{X}$ & $\mathrm{x}$ & $\mathrm{X}$ & $\mathrm{x}$ & & & & & & \\
\hline Sciaenops ocellatus & Red drum & Lârva & & & & & & $\mathrm{x}$ & & & & & & \\
\hline Menticirrhus americanus & Southern kingfish & Larva & & & & & & $x$ & & & & & & \\
\hline Leiostomus xanthurus & Spot & Larva-juvenile & & $x$ & $x$ & & $\mathrm{x}$ & & & & & & & $x$ \\
\hline Micropogonias undulatus & Atlantic croaker & Larva & & & & & & $\mathrm{x}$ & $\mathrm{x}$ & & $\mathrm{X}$ & $x>$ & $x$ & \\
\hline Bairdiella chrysoura & Silver perch & Larva & & & & & & $\mathrm{x}$ & & & & & & \\
\hline Sciaenidae & Drums & Egg & & & $\mathrm{X}$ & $\mathrm{x}$ & $\mathrm{X}$ & $\mathrm{x}$ & & & & & & \\
\hline Tautoga onitis & Tautog & $\mathrm{Egg}$ & & $x$ & & & & & & & & & & \\
\hline Astroscopus guttatus & Stargazer & Larva & & & & & $\mathrm{X}$ & & & & & & & \\
\hline Hypsoblennius hentzi & Feather blenny & Larva & & & $\mathrm{X}$ & $\mathrm{x}$ & $\mathrm{X}$ & $\mathrm{x}$ & & $X$ & & & & \\
\hline Chasmodes bosquianus & Striped blenny & Larva & & & & & $\mathrm{X}$ & & & & & & & \\
\hline Ammodytes americanus & Sand lance & Larva & & & & & & & & & & & & $\mathrm{X}$ \\
\hline Gobiosoma ginsburgi & Seaboard goby & Larva & & & & & & $\mathrm{x}$ & $\mathrm{X}$ & & & $\mathrm{X}$ & & \\
\hline Gobiosoma bosci & Naked goby & Larva & & & & & & & & $\mathrm{x}$ & & & & \\
\hline Gobiosoma sp. & Gobies & Egg-larva & & & $\mathrm{X}$ & $\mathrm{X}$ & $x$ & $\mathrm{x}$ & & & & & & \\
\hline Microgobius thalassinus & Green goby & Larva & & & & $\mathrm{X}$ & $\mathrm{X}$ & $x$ & & & & & & \\
\hline Gobionellus hastatus & Sharptail goby & Larva & & & & & & & & $\mathrm{x}$ & & & & \\
\hline Peprilus paru & Harvestfish & Larva & & & & & & $x$ & & & & & & \\
\hline Paralichthys dentatus & Summer flounder & Larva & $x$ & $\mathrm{x}$ & & & & & & & $\mathrm{x}$ & $x$ & $\mathrm{X}$ & $\mathrm{x}$ \\
\hline Scopthalmus aquosus & Windowpane & Egg-Larva & $x$ & $x$ & $\mathrm{X}$ & & & & & & & & & \\
\hline Pseudopleuronectes americanus & Winter flounder & Larva & $x$ & & & & & & & & & & & \\
\hline Trinectes maculatus & Hogchoker & Egg-Larva & & & & $\mathrm{X}$ & & $x$ & & & & & & \\
\hline Symphurus plagiusa & Blackcheek tonguefish & Larvae & & & & & & $x$ & & & & & & \\
\hline Sphoeroides maculatus & Northern puffer & Larvae & & & & & & $\mathrm{x}$ & & & & & & \\
\hline Unknown & - & Eggs & & $\mathrm{x}$ & $x$ & & & & & & & & & \\
\hline
\end{tabular}


Fig. 4. Seasonality of the abundance of total fish eggs and larvae by habitat (Zostera, Ruppia, or Sand) throughout the course of the study. Values are the mean of duplicate samples. (A) Fish eggs. (B) Fish larvae
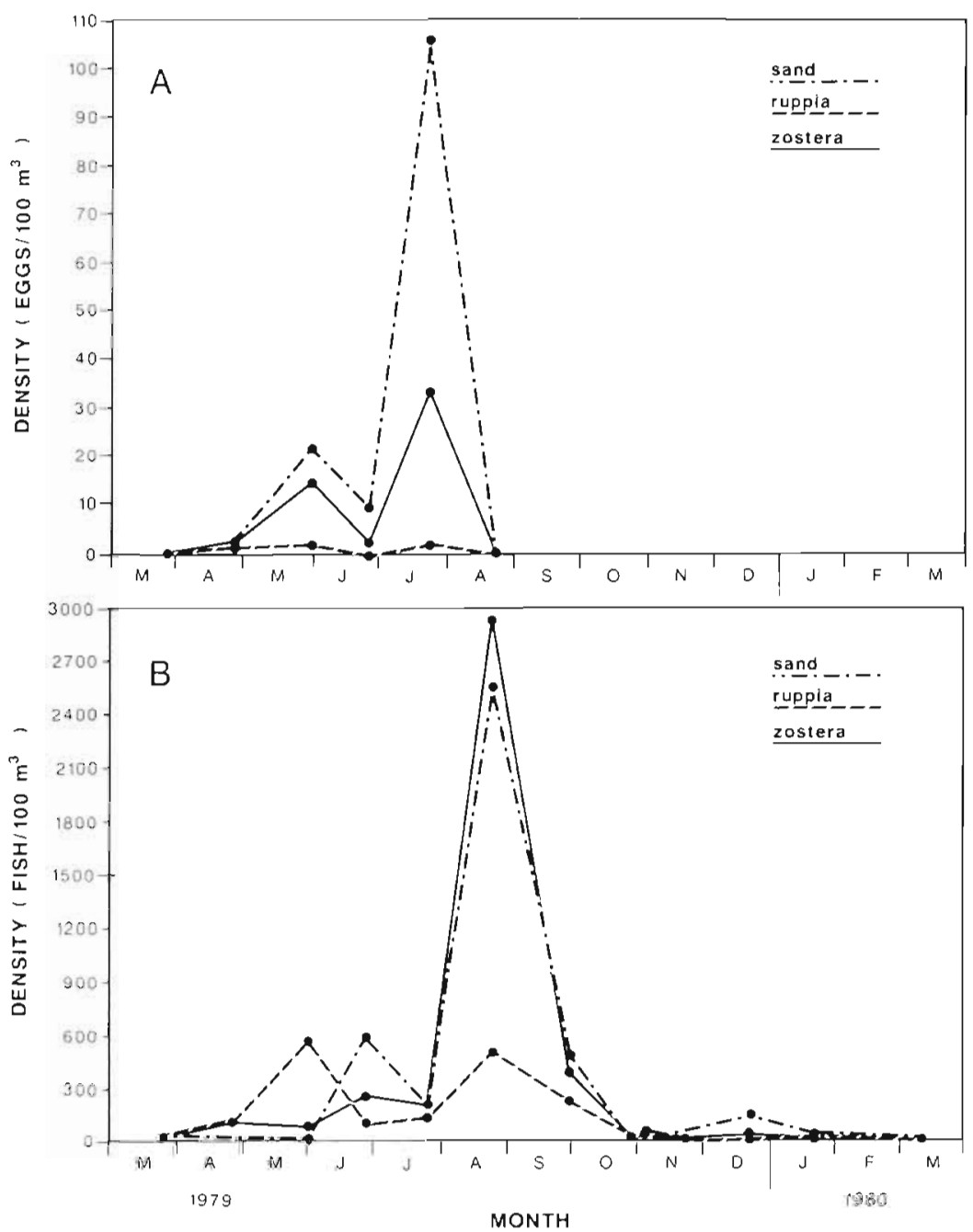

species, Anchoa mitchilli, dominated collections, comprising $72 \%$ of all fishes captured. The remaining 7 species in order of decreasing abundance were the goby Gobiosoma sp. (8.9\%), juvenile menhaden Brevoortia tyrannus $(6.06 \%)$, larval through adult northern pipefish Syngnathus fuscus $(3.9 \%)$, larval and early juvenile croaker Micropogonias undulatus $(2.2 \%)$, juvenile and adult rough silverside Membras martinica $(1.3 \%)$, larval and early juvenile spot Leiostomus xanthurus $(1.2 \%)$, and unidentified atherinid larvae $(1.1 \%)$. Larval or juvenile stages were present during all months sampled (Fig. 4B). Mean abundance of fishes in all habitats gradually increased throughout the spring to a midsummer peak, generally reflecting maximum densities of larval anchovies.

We compared day and night pushnet catches in May

Table 2. Day versus night pushnet catch (numbers $100 \mathrm{~m}^{-3}$ ) comparison. August 1979. Pelagic egg abundance estimates are excluded. Totals for all species at night include densities of several species not captured in day samples. Abbreviations are: $S$, sand; $R$, Ruppia maritima; $Z$, Zostera marina; $T$, total fishes captured in all habitats divided by total water volume filtered

\begin{tabular}{|lcrrrrrrr|}
\hline Species & \multicolumn{3}{c}{ Day } & \multicolumn{3}{c}{} & & \multicolumn{2}{c|}{ Night } \\
& $\mathrm{S}$ & $\mathrm{R}$ & $\mathrm{Z}$ & $\mathrm{T}$ & $\mathrm{S}$ & $\mathrm{R}$ & $\mathrm{Z}$ & $\mathrm{T}$ \\
\hline Anchoa mitchilli & 97.2 & 2.9 & 46.4 & 54.7 & 2378.8 & 283.0 & 2648.8 & 1838.3 \\
Atherinid larvae & 2.8 & 3.9 & 1.0 & 2.6 & 1.5 & 46.9 & 14.3 & 19.4 \\
Syngnataus fuscus & 1.2 & 0.6 & 0.5 & 0.8 & 10.0 & 39.2 & 10.1 & 48.8 \\
Gobiosoma sp. & 0 & 0 & 0.5 & 0.2 & 65.9 & 74.8 & 150.2 & 96.7 \\
All species & 101.2 & 7.4 & 48.5 & 58.2 & 2513.1 & 474.1 & 2978.4 & 2055.2 \\
\hline
\end{tabular}




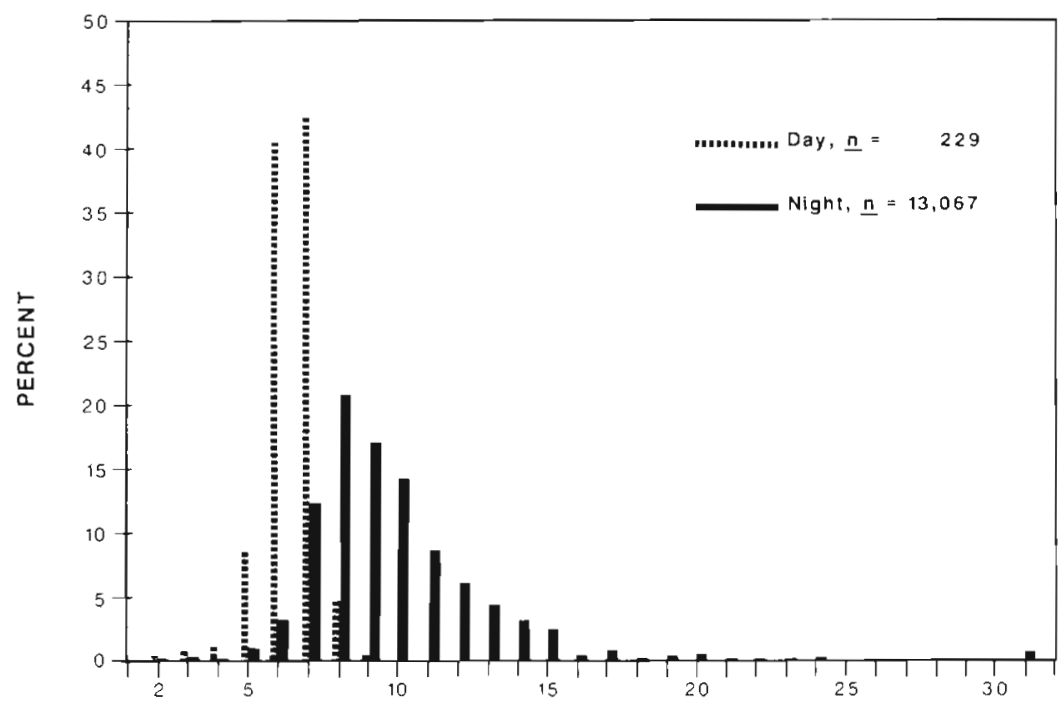

Fig. 5. Anchoa mitchilli. Day-night difference in the length frequency of larvae captured by pushnet in August 1979

STANDARD LENGTH $(\mathrm{mm})$

and August. In both months, mean density estimates for all species in each habitat as well as total fishes captured in all habitats were much greater at night. In August 1979, when larvae were more abundant (Fig. 4B), 17 species of fish were captured at night, but only 4 species were taken in day collections (Table 2). Bay anchovies dominated collections, with density estimates of larvae in night collections significantly exceeding those in daylight collections. In addition, size-frequency analysis of day- versus night-caught larvae revealed extreme disparity in larval size distribution (Fig. 5). Anchovies larger than $9.0 \mathrm{~mm} \mathrm{SL}$ were not taken during daylight hours but were a significant component of the night anchovy catch. These large specimens were either migrating to the upper meter from a deeper daytime distribution (Hunter \& Sanchez 1976) or were not captured during daylight hours due to gear avoidance. It should be pointed out that the smallest sizes of newly hatched Anchoa mitchilli ( 2 to $4 \mathrm{~mm} \mathrm{SL}$ ) may be under-represented in our collections due to extrusion through the meshes (Houde \& Lovdal 1984). This may also apply to small sciaenids. In comparisons between the remaining 3 species, size ranges did not differ markedly, but density estimates of silverside, goby, and pipefish larvae were greater in night collections. Because day densities represent a small percentage of night densities, daylight samples were not considered further in our analysis.

The bay anchovy Anchoa mitchilli was clearly the dominant species throughout our study. Peak monthly densities of bay anchovies were recorded in all habitats in June to September 1979, a 4 mo period that includes the time of peak spawning (Olney 1983) and during which larval and early juvenile stages dominated collections (Fig. 6A). Bay anchovies were present in push- net samples during all sampling periods and in all habitats during each sampling period with the exception of March 1979 Ruppia collections. In general, monthly mean densities of bay anchovies varied only slightly between habitats, with the exception of August 1979. During this period of peak abundance, larval anchovies were conspicuously less abundant over Ruppia beds. Numerically, pushnet catches over Ruppia contributed only $9.6 \%$ of the total anchovies taken during the study, while densities of anchovies over sand and Zostera beds appeared to be habitatindependent. The length-frequency distributions of bay anchovies show growth of the cohort between July and October. Based upon median sizes in the dominant mode of smaller larvae in July through October, the growth rate estimates were $0.13 \mathrm{~mm} \mathrm{~d}^{-1}$ (July-August), $0.29 \mathrm{~mm} \mathrm{~d}^{-1}$ (August-September), and $0.79 \mathrm{~mm} \mathrm{~d}^{-1}$ (September-October). Continued recruitment of newly hatched fish in August makes the first estimate low, but the second two are probably good estimates of field growth rate for this species. The mean of these 2 values, $0.54 \mathrm{~mm} \mathrm{~d}^{-1}$, agrees well with observations of growth rates in the laboratory (Houde 1974, Houde \& Schekter 1981) and field (Leak \& Houde 1987).

Catches were dominated by juvenile and adult anchovies (fishes $>30 \mathrm{~mm} \mathrm{SL}$ ) in March to May 1979 and October to December 1979. Larval anchovies appeared in collections in May 1979, corresponding to the time of first occurrence of pelagic eggs (Fig. 4A). By September 1979, spawning had apparently ceased and no early larval stages appeared in collections. Young anchovies ranged from 10 to $32 \mathrm{~mm}$ SL and this larval cohort dominated September catches. Late larval and early juvenile stages (16 to $30 \mathrm{~mm}$ SL) remained in pushnet collections throughout the remainder of 
sampling (October 1979 to March 1980), apparently a period of minimal growth. The presence of specimens smaller than $30 \mathrm{~mm}$ SL taken in November, however, suggests that a minor late spawning may have occurred after that in the May to August period. The occurrence of these small fish, however, was sporadic; they seemed absent in December but were present again in March 1980. The presence of 30 to $50 \mathrm{~mm}$ SL fish in May through June 1979 suggests that this late spawning occurred in 1978 as well.

Different species groups showed clear temporal patterns (Table 3). Seasonality of pushnet-collected
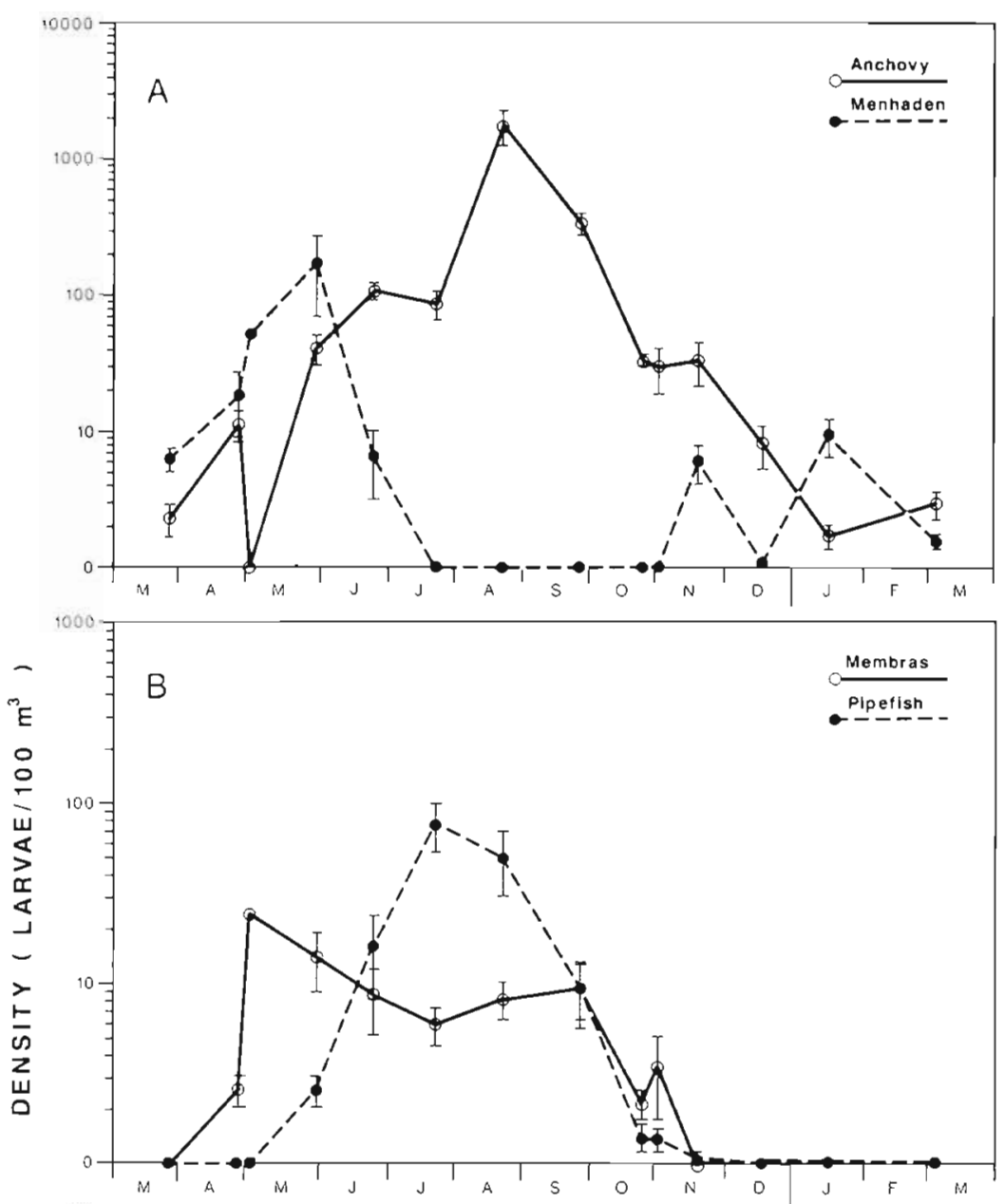

Fig. 6. Seasonal abundance of larvae of the principal taxa from all 3 habitats combined. Values are means of all observations, with bars representing \pm 1 SE. (A) Bay anchovy Anchoa mitchilli and Atlantic menhaden Brevoortia tyrannus. (B) Northern pipefish Syngnathus fuscus and rough silverside Membras martinica. (C) Spot Leiostomus xanthurus and Atlantic croaker Micropogonias undulatus

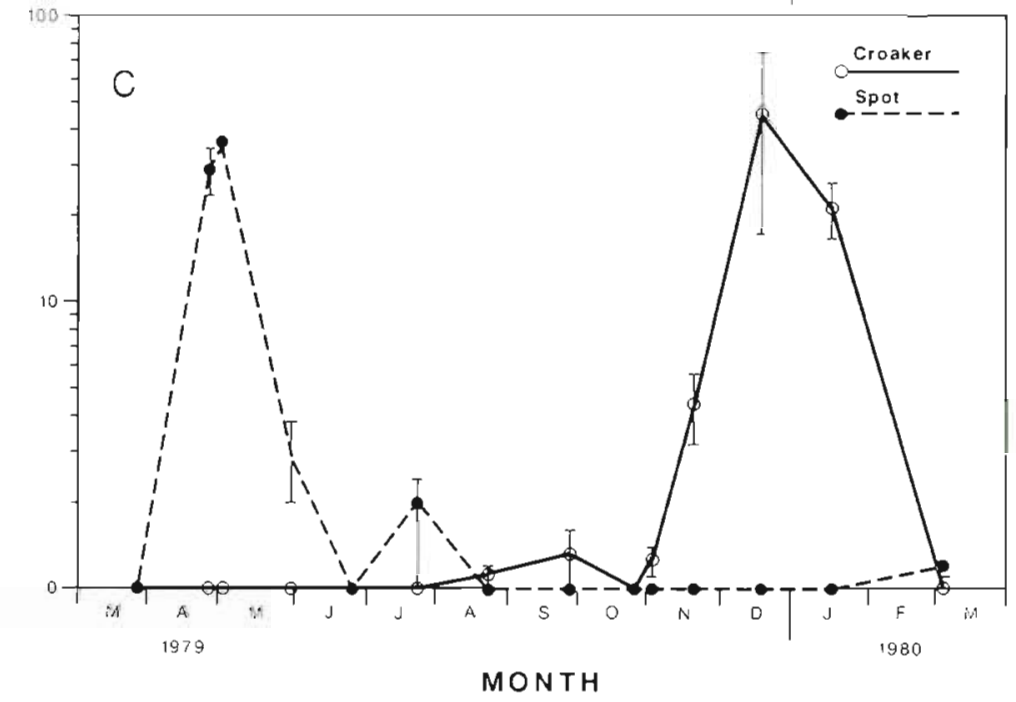


Table 3. Summary of seasonal ichthyoplankton assemblages in nearshore habitats in Chesapeake Bay. Species life history stages (E: egg; L: larva; J: juvenile; A: adult), surface temperature range and months of collection are reported from pushnet collections, March 1979 to March 1980

\begin{tabular}{|c|c|c|c|}
\hline $\begin{array}{l}\text { Surface temperature } \\
\text { range }\left({ }^{\circ} \mathrm{C}\right)\end{array}$ & Season (months) & Characteristic species & Life history stages \\
\hline $1-12$ & $\begin{array}{l}\text { Winter } \\
\text { (Nov-Mar) }\end{array}$ & $\begin{array}{l}\text { Ammodytes americanus } \\
\text { Brevoortia tyrannus } \\
\text { Paralich thys dentatus } \\
\text { Anguilla rostrata } \\
\text { Micropogonia undulatus } \\
\text { Anchoa mitchilli } \\
\text { Menidia menidia }\end{array}$ & $\begin{array}{l}\text { L } \\
\text { L, J } \\
\text { L, J } \\
\text { Elver } \\
\text { L } \\
\text { J, A } \\
\text { J, A }\end{array}$ \\
\hline $15-22$ & $\begin{array}{l}\text { Spring } \\
\text { (Apr-May) }\end{array}$ & $\begin{array}{l}\text { Leiostomus xanthurus } \\
\text { B. tyrannus } \\
\text { Membras martinica } \\
\text { A. mitchilli } \\
\text { Scopthalmus aquosus } \\
\text { Atherinidae } \\
\text { Syngnathus fuscus } \\
\text { Sciaenidae }\end{array}$ & $\begin{array}{l}\text { L, J } \\
\text { L, J } \\
\text { J, A } \\
\text { E, L, J,A } \\
\text { E, L } \\
\text { L } \\
\text { A } \\
\text { E }\end{array}$ \\
\hline $20-28$ & $\begin{array}{l}\text { Summer } \\
\text { (Jun-Aug) }\end{array}$ & $\begin{array}{l}\text { A. mitchilli } \\
\text { Gobiosoma sp. } \\
\text { A. hepsetus } \\
\text { S. fuscus } \\
\text { Sciaenidae } \\
\text { M. martinica } \\
\text { Atherinidae } \\
\text { Microgobius thalassinus } \\
\text { Hyporhamphus sp. } \\
\text { H. hentzi }\end{array}$ & $\begin{array}{l}\text { E, L, J, A } \\
\text { L } \\
\text { L } \\
\text { L, } \\
\text { E, L, J } \\
\text { E, J, A } \\
\text { L } \\
\text { L } \\
\text { E, L } \\
\text { L }\end{array}$ \\
\hline $13-21$ & $\begin{array}{l}\text { Fall } \\
\text { (Sep-Oct) }\end{array}$ & $\begin{array}{l}\text { A. mitchilli } \\
\text { Membras martinica } \\
\text { S. fuscus } \\
\text { H. hentzi }\end{array}$ & $\begin{array}{l}\text { L, J, A } \\
\text { J, A } \\
\text { J, A } \\
\text { L, J }\end{array}$ \\
\hline
\end{tabular}

fishes was related to water temperature, with higher densities in warmer months (Figs. 3 and 4). Winter pushnet collections (November to March) were characterized by larvae or early juveniles of 5 species of offshore spawners, specifically Ammodytes americanus, Brevoortia tyrannus (Fig. 6A), Paralichthys dentatus, Anguilla rostrata and Micropogonias undulatus (Fig. 6C). Larval stages of these fishes (elvers in the case of American eel) enter the Chesapeake Bay when surface water temperatures ranged from 1 to $12^{\circ} \mathrm{C}$. Patterns and mechanisms of immigration into the bay are unknown, but the presence of these stages in nearshore habitats along the eastern bay margin is probably related to Bay salinity patterns. The eastern bay margin is characterized by a high salinity salt wedge intrusion (Boicourt 1981). Late stage larvae may utilize the non-tidal, upriver vector of this intrusion as a mechanism in recruitment to the estuary. The absence of dense Zostera or Ruppia beds during the winter precludes utilization of SAV habitat. In addition to immigrant larvae, resident populations of juvenile and adult Anchoa mitchilli and Menidia menidia occupy nearshore waters during winter (Fig. 6).

With increasing surface temperatures $\left(15\right.$ to $\left.22^{\circ} \mathrm{C}\right)$, spring pushnet collections revealed the continued presence of Brevoortia tyrannus larvae and juveniles as well as resident populations of juvenile and adult anchovies and rough silversides (Fig. 6). Larval and juvenile spot Leiostomus xanthurus became most abundant (Fig. 6C, Table 3). Resident populations of juvenile and adult anchovies and rough silversides were apparent (Fig. 6A, B). Spawning activity of bay anchovies, sciaenids, and windowpane flounder Scopthalmus aquosus were responsible for the increased egg densities during this period (Fig. 4A). Atherinid spawning and the presence of adult Syngnathus fuscus and young spot in collections coincide with the initiation of SAV growth.

The summer SAV ichthyoplankton assemblage was characterized by high densities (Fig. 4) and was dominated by egg and larval stages of resident lower Chesapeake Bay spawners including anchovies, 
gobies, pipefish (Fig. 6B), sciaenids (Cynoscion regalis, Menticirrhus americanus, Sciaenops ocellatus, and Bairdiella chrysoura), atherinids, blennies, and halfbeaks (Table 3). In addition, some immigration of offshore (or coastal) spawned larvae was observed, namely Anchoa hepsetus. Summer pushnet collections revealed peaks in density and diversity of nearshore ichthyoplankton populations but habitat comparison data (Fig. 4) confirmed that these peaks were independent of the presence of dense SAV beds. The high numerical rank abundance of goby and pipefish larvae, however, was clearly a function of water depth and the presence of vegetation. This conclusion is based on the relative importance of the species in ichthyoplankton surveys of deeper waters in the Bay (Pearson 1941, Olney 1983). Late stage larval, juvenile, and adults of 4 species, all resident lower Bay fishes, were present in fall (September, October) pushnet collections. During this period, density and diversity of the catch were low and little evidence of SAV dependence was observed (Fig. 4).

\section{DISCUSSION}

Studies of ichthyoplankton distribution have recently shown that many difficult-to-sample habitats may harbor significant populations of larval fishes. These include the epibenthic stratum (Jahn \& Lavenberg 1986), the surf zone (Senta \& Kinoshita 1985), near rocky reefs (Marliave 1986, Kobayashi 1987), shallow waters of estuaries (Powles et al. 1984), and seagrass beds, as shown in the present study. We noted moderate abundances of larvae which were either rare (Micropogonius undulatus) or unreported (Anchoa hepsetus, Sciaenops ocellatus) in previous studies in the Chesapeake Bay (Pearson 1941, Olney 1983). Conversely, species abundant in main channel areas, including Cynoscion regalis and Trinectes maculatus, were rare in our samples.

While our data demonstrate that nearshore vegetated habitats in lower Chesapeake Bay are not important spawning sites for species with pelagic eggs (Fig. 4A), they are clearly important for some species that either brood young (syngnathids) or have demersal eggs (atherinids). Certain other estuarine species with demersal eggs or nesting habitats, including gobies, blennies, or toadfish Opsanus tau, frequently occur within SAV habitats during spawning periods, but are probably not dependent upon these habitats. In our study the dominant species were either widely distributed across all habitats (bay anchovy, menhaden) or transients making short-term utilization of the seagrass habitat. Some of these species, such as spot, may in fact be more abundant in tidal creeks (Weinstein 1979) or other unvegetated areas (Heck \& Thoman 1984).
Weinstein \& Brooks (1983) suggested that shallow tidal creeks may be the preferred habitat, and as these become saturated with young spot, the less preferred vegetated habitats are utilized. Thus, the importance of seagrass beds as spawning sites and as an early larval nursery habitat may be questioned.

Bell \& Westoby (1986a) conducted experiments with artificially reduced seagrass densities and caged and uncaged treatments. Their results suggested that abundance of macrofauna in seagrass beds is a function of habitat preference rather than lower predation rates. Later, however, they attributed a selective advantage to species with early life history stages using the complex seagrass habitats to reduce predation (Bell $\&$ Westoby 1986 b). This protection role may be questioned for early life history stages of fishes and the degree of protection may relate to the stage of ontogenetic development. It is clear that the complex habitat provided by seagrass may provide protection for animals able to orient to the blades under certain conditions (Heck \& Thoman 1981, Minello \& Zimmerman 1983). Breitburg (1987), for example, observed presettlement larval Gobiosoma bosci schooling within $0.5 \mathrm{~m}$ of the substrate in Chesapeake Bay. The same habitat complexity, however, often results in higher densities of animals which prey on early life history stages of fish and plankton in particular. In kelp forests, for example, fishes remove significant portions of the plankton flowing through (Bray 1980); Gaines \& Roughgarden (1987) showed that predation by planktivorous fishes in nearshore kelp beds had a negative effect on recruitment of intertidal barnacles. Seasonally high abundances of planktivorous fishes such as silverside, spot, silver perch, pipefish, and other species (Orth \& Heck 1980) may result in SAV beds serving as 'sinks' for pelagic eggs and early larvae, which are unable to orient to the seagrass blades. Leak \& Houde (1987) observed predation related mortality of 18 to $28 \% \mathrm{~d}^{-1}$ for Anchoa mitchilli larvae in Biscayne Bay, Florida, USA. In our study, the major difference in abundance between day and night pushnet samples (Fig. 5) for this species may be partially the result of predation, since planktivores typically feed during daylight hours (Ryer \& Boehlert 1983). The ratios of night to day densities of bay anchovy larvae by habitat in August were 24.5, 97.6, and 57.2 for sand, Ruppia, and Zostera areas, respectively. The dramatically greater decrease in day densities in vegetated areas may thus be in part related to local abundance of predators.

As opposed to early larval stages, the refuge function of seagrass may be well served for late larvae and juveniles of some species, such as menhaden, spot, and silverside. The increased development of sensory systems and swimming capabilities in older larvae (Fukuhara 1987) may make them better able to evade 
many predators in seagrass. This would agree with suggestions that post-settlement mortality from predation is relatively unimportant (Bell et al. 1987). Lascara (1981) demonstrated through laboratory experiments that larger, predatory fishes such as bluefish or weakfish are less able to prey upon juvenile fishes with increasing seagrass density. Similar results were noted by Savino \& Stein (1982), who further attributed these effects both to increases in visual barriers for predators and adaptive changes in behavior of the prey species; early larvae may be unable to exhibit such behavior patterns. A further benefit to late larval stages in estuarine environments may be lower densities (or reduced predatory capabilities) of gelatinous predators, which can have important impacts upon fish larvae (van der Veer 1985).

That estuaries serve as important nursery habitats for early life history stages of fishes has been clearly demonstrated (Weinstein et al. 1980, Boehlert \& Mundy 1987). Our study shows that the nearshore and seagrass habitats in the Chesapeake Bay are characterized by many species which are not commonly found in the midchannel ichthyoplankton as described by Olney $(1978,1983)$ and others. A full characterization of ichthyoplankton communities requires examination of nearshore, nearbottom, and other difficult-to-sample habitats, many of which will require novel or new sampling methodologies.

Acknowledgements. We thank a number of individuals for assistance in the field sampling efforts, particularly Hugh Brooks, Joe Lascara, Cathy Meyer, Jacque Carter, and Joe Gawoni. This research was funded in part by the US Environmental Protection Agency's Chesapeake Bay Program, Grant No. R805974. We thank H. G. Moser, R. Orth, C. Ryer and M. $P$. Weinstein for critical reviews of this manuscript. This is contribution No. 1448 of the Virginia Institute of Marine Science of the College of William and Mary

\section{LITERATURE CITED}

Adams, S. M. (1976). The ecology of eelgrass, Zostera marina (L.), fish communities. I. Structural analysis. J. exp. mar. Biol. Ecol 2: 269-291

Bell, J. D., Westoby, M. (1986a). Abundance of macrofauna in dense seagrass beds is due to habitat preference, not predation. Oecologia (Berl.) 68: 205-209

Bell, J. D., Westoby, M. (1986b). Variation in seagrass height and density over a wide spatial scale: effects on common fish and decapods. J. exp. mar. Biol. Ecol. 104: 275-295

Bell, J. D., Westoby, M., Steffe, A. S. (1987). Fish larvae settling in seagrass: do they discriminate between beds of different leaf density? J. exp. mar. Biol. Ecol. 111: 133-144

Blaber, S. J. M., Blaber, T G. (1980). Factors affecting the distribution of juvenile estuarine and inshore fish. J. Fish Biol. 17. 143-162

Boehlert, G. W., Morgan, J. B. (1985). Turbidity enhances feeding abilities of larval Pacific herring, Clupea harengus pallasi. Hydrobiologia 123: 161-170
Boehlert, G. W., Mundy, B. C. (1988). The role of behavioral and physical factors in fish recruitment, to estuarine nursery areas. Trans. Am. Fish. Soc. Symp. 3: 51-67

Boicourt, W. C. (1981). Circulation in the Chesapeake Bay entrance region: estuary-shelf interaction. In: Campbell, J. C., Thomas, J. P. (eds.) Chesapeake Bay plume study. NASA Conference Publication 2188: 61-78

Bray, R. N. (1980). Influence of water currents and zooplankton densities on daily foraging movements of blacksmith, Chromis punctipinnis, a planktivorous reef fish. Fish. Bull. U. S. 78: 829-843

Breitburg, D. (1987). Larval schooling behavior of a nonschooling benthic fish species. EOS (Trans. Am. Geophys. Un.) 68: 1750

Carr, W. E. S., Adams, C. A. (1973). Food habits of juvenile marine fishes occupying seagrass beds in the estuarine zone near Crystal River, Florida. Trans. Am. Fish. Soc. 102 $511-540$

Dovel, W. (1971). Fish eggs and larvae of the upper Chesapeake Bay Natl Res. Inst., Univ. Maryland Contrib. No. 460: 1-71

Fukuhara, O. (1987). Larval development and behavior in early life stages of black sea bream reared in the laboratory. Bull. Jap. Soc. scient. Fish. 53: 371-380

Gaines, S. D., Roughgarden, J. (1987). Fish in offshore kelp forests affect recruitment to intertidal barnacle populations. Science 235: 479-481

Heck, K. L., Jr, Thoman, T. A. (1981). Experiments on predator-prey interactions and vegetated aquatic habitat. J. exp. mar. Biol. Ecol. 53: 125-134

Heck, K. L., Jr, Thoman, T A. (1984). The nursery role of seagrass meadows in the upper and lower reaches of the Chesapeake Bay. Estuaries 7: 70-92

Hillman-Kitalong, A., Birkeland, C. (1987). Comparative biases from pushnet und pullnet zooplankton samples Mar. Ecol. Prog. Ser. 38: 131-135

Houde, E. D. (1974). Effects of temperature and delayed feeding on growth and survival of larvae of three species of subtropical marine fishes. Mar. Biol. 26: 271-285

Houde, E. D., Loval, J. A. (1984). Seasonality of occurrence, foods, and food preferences of ichthyoplankton in Biscayne Bay, Florida. Estuar. coast. Shelf Sci. 18: 403-420

Houde, E. D., Schekter, R. C., (1981). Growth rates, rations and cohort consumption of marine fish larvae in relation to prey concentrations. Rapp. P. v. Réun. Cons. int. Explor Mer 178: 441-453

Hunter, J. R., Sanchez, C. (1976). Diel changes in swimbladder inflation of the larvae of the northern anchovy, Engraulis mordax. Fish. Bull. U. S. 74: 847-855

Jahn, A. E., Lavenberg, R. J. (1986). Fine-scale distribution of nearshore, suprabenthic fish larvae. Mar Ecol. Prog. Ser. 31: 223-231

Kobayashi, D. R. (1987). The distribution and abundance of certain reef fish larvae adjacent to adult habitats in Kaneohe Bay. Hawaii. M. S. thesis, Univ. of Hawaii, Honolulu

Lascara, J. (1981). Fish predator-prey interactions in areas of eelgrass (Zostera marina). M. A. thesis, College of William and Mary, Williamsburg, Virginia

Leak, J. C., Houde, E. D. (1987). Cohort growth and survival of bay anchovy Anchoa mitchilli larvae in Biscayne Bay, Florida. Mar Ecol. Prog. Ser. 37: 109-122

Marliave, J. B. (1986). Lack of planktonic dispersal of rocky intertidal fish larvae. Trans. Am. Fish. Soc. 115: 149-154

Miller, J. M. (1973). A quantitative push-net system for transect studies of larval fish and zooplankton. Limnol. Oceanogr 18: 175-178 
Miller, J. M., Reed, J. P., Pietrafesa, L. J. (1984). Patterns, mechanisms, and approaches to the study of migrations of estuarine-dependent fish larvae and juveniles. In: McCleave, J. D., Arnold, G. P., Dodson, J. J., Neill. W. H. (eds.) Mechanisms of migration in fishes. Plenum Press, New York, p. 209-225

Minello, T J., Zimmerman, R. J. (1983). Fish predation on juvenile brown shrimp. Penaeus aztecus lves: the effect of simulated Spartina structure on predation rates. J. exp. mar Biol. Ecol. 72: 211-231

Olney, J. E. (1978). Planktonic fish eggs and larvae of the lower Chesapeake Bay. M. S. thesis, College of William and Mary, Williamsburg, Virginia

Olney, J. E. (1983). Eggs and early larvae of the bay anchovy. Anchoa mitchilli, and the weakfish, Cynoscion regalis, in lower Chesapeake Bay with notes on associated ichthyoplankton. Estuaries 6: 20-35

Orth, R. J., Heck, K. L., Jr (1980). Structural components of eelgrass (Zostera marina) meadows in the lower Chesapeake Bay: fishes. Estuaries 3: 278-288

Orth, R. J., Moore, K. A. (1983). Chesapeake Bay: an unprecedented decline in submerged aquatic vegetation. Science 222: 51-53

Pearson, J. C. (1941). The young of some marine fishes taken in lower Chesapeake Bay, Virginia, with special reference to the grey sea trout, Cynoscion regalis (Bloch). U. S. Fish Wildl. Serv., Fish. Bull. 50: 79-102

Powles, H., Auger, F., Fitzgerald, G. J. (1984). Nearshore ichthyoplankton of a north temperate estuary. Can. J. Fish. aquat. Sci. 41: 1653-1663

Reid, G. K., Jr (1954). An ecological study of the Gulf of
Mexico fishes, in the vicinity of Cedar Keys, Florida. Bull. mar. Sci. Gulf. Caribb. 4: 1-94

Rosenberg, A. A. (1982). Growth of juvenile English sole, Parophrys vetulus, in estuarine and open coastal nursery areas. Fish. Bull. U. S. 80: 245-252

Ryer, C. H., Boehlert, G. W. (1983). Feeding periodicity, daily ration, and the effects of temperature upon gastric evacuation in the pipefish, Syngnathus fuscus. Environ. Biol. Fish. 9: 301-306

Savino, J. F., Stein, R. A. (1982). Predator-prey interaction between largemouth bass and bluegills as influenced by simulated, submersed vegetation. Trans. Am. Fish. Soc. $111 \cdot 255-256$

Senta, T., Kinoshita, I. (1985). Larval and juvenile fishes occurring in surf zones of western Japan. Trans. Am. Fish. Soc. 114: 609-618

van der Veer, H. W. (1985). Impact of coelenterate predation on larval plaice Pleuronectes platessa and flounder Platichthys flesus stock in the western Wadden Sea. Mar Ecol. Prog. Ser. 25: 229-238

Weinstein, M. P. (1979). Shallow marsh habitats as primary nurseries for fishes and shellfish, Cape Fear River, North Carolina. Fish. Bull. U. S. 77-339-358

Weinstein, M. P., Brooks, H. A. (1983). Comparative ecology of nekton residing in a tidal creek and adjacent seagrass meadow: community composition and structure. Mar. Ecol. Prog. Ser. 12: 15-27

Weinstein, M. P., Weiss, S. L., Hodson, R. G., Gerry, L. R. (1980). Retention of three taxa of postlarval fishes in an intensively flushed tidal estuary, Cape Fear River, North Carolina. Fish. Bull. U. S. 78: 419-436 